\title{
Occupational skin cancer: Systematic review
}

Jéssica Suellen Sena ${ }^{1 *}$, Régio José Santiago Girão², Sionara Melo Figueiredo de Carvalho³, Rosielly Melo Tavares ${ }^{1}$, Fernando luiz Affonso Fonseca ${ }^{4}$, Patrícia Barros Aquino Silva ${ }^{1}$, Maria Clara Fortes Portela Barbosa ${ }^{1}$

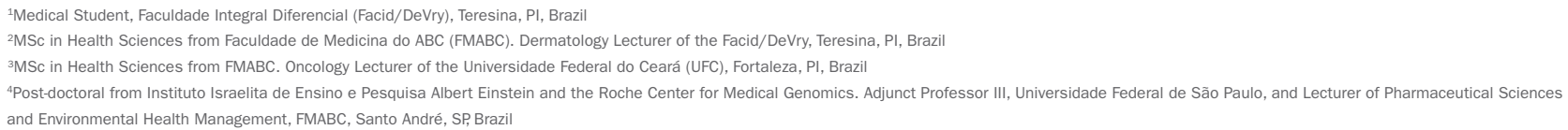

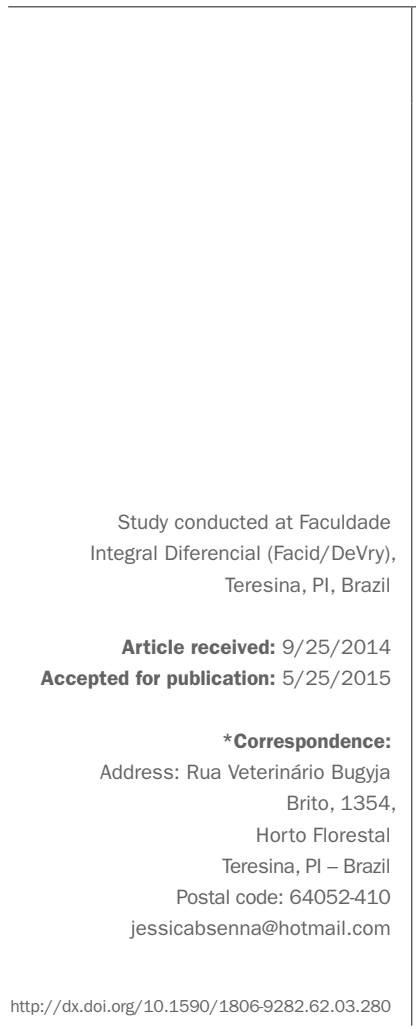

\section{SUMmARY}

Objective: To analyze the epidemiological profile, risk factors in the workplace environment and prevention methods for professionals at risk of skin cancer. Method: A systematic review of articles on occupational skin cancer, published in the Lilacs, Scielo, Medline and Cochrane Library from January $1^{\text {st }}, 2008$, to December $31^{\text {st }}, 2013$, was performed. The search included the following terms: "neoplasias cutâneas" (DeCS), "exposição ocupacional” (DeCS), "epidemiologia” (DeCS) as well as the keyword "prevenção", and their equivalents in English.

Results: After analyzing the titles and summaries of articles, the search strategy resulted in 83 references, of which 22 articles met the eligibility criteria.

Discussion: We found that sun exposure is the main occupational risk factor for skin cancer, causing outdoor workers to be the most vulnerable to developing occupational skin cancer. Professionals with low levels of education and European descent are at increased risk of developing this cancer.

Conclusion: Outdoor workers are more vulnerable to developing occupational skin cancer, estimating that professionals with low level of education and European descent are at increased risk of developing this cancer. Therefore, companies need to invest more in the health of workers by providing protective equipment and thus preventing occupational skin cancer.

Keywords: skin cancers, occupational exposure, disease prevention, epidemiology.

\section{INTRODUCTION}

Occupational cancer occurs when professionals are exposed to certain substances or a combination of these at work. This is caused most often due to misinformation about the health risks, favoring greater exposure to these substances inadvertently. ${ }^{1}$

Workplaces generally have a greater concentration of carcinogens than other environments outside of work. ${ }^{2}$ In view of this, exposure to numerous risk factors both at work and in the non-occupational environment as well as favorable climatic conditions may favor the emergence of skin cancer. ${ }^{3-5}$

The main risk factor associated with the development of this neoplasm is exposure to UV radiation. It causes chronic cutaneous photoaging as well as having a carcinogenic effect on the skin in two ways: directly, when it acts directly on the cell, causing DNA mutation, and indirectly, by causing induction of T lymphocytes. ${ }^{3-5}$
Interest in this research occurred due to the fact that skin cancer may be the neoplasm that is most incident and avoidable in Brazil, as well as the major association with certain professional activities owed to exposure to numerous risk factors at work in a prolonged or cumulative manner. ${ }^{1,2,5,12}$

As such, the objectives of the study were: To analyze the epidemiological profile, the risk factors in the work environment and the prevention methods for professionals at risk of skin cancer. Furthermore, the sociodemographic variable of the professionals at risk was verified, identifying the professionals related to the risk of acquiring skin cancer and effective protection methods.

\section{Method}

A systematic review of the scientific literature relating to the topic of occupational skin cancer was conducted. The methodology used was based on studies located in the 
Lilacs, Scielo, Medline and the Cochrane Library databases. The search for articles was performed in February 2014 and was limited to articles published between January $1^{\text {st }}$, 2008, and December 31 ${ }^{\text {st }}, 2013$.

Initially, the search strategy was based on the intersection of the following terms:

- \#1 "Skin neoplasms" (DeCS);

- \#2 "Occupational exposure" (DeCS);

- \#3 "Epidemiology" (DeCS);

- \#4 "Prevention" (keyword).

The following searches were conducted: $\# 1$ and $\# 2 ; \# 1$ and $\# 3$; \#1 and \#4. A search with the above terms in Portuguese was performed subsequently. The articles found using this strategy were firstly selected using their titles and abstracts.

The analysis of the articles followed subsequently inclusion and exclusion criteria. We included: a) articles that presented at least one combination of the established terms in the title; b) manuscripts in English or Portuguese; c) original texts with full online access; d) prospective or retrospective observational (descriptive or analytical), experimental or quasi-experimental studies. We excluded: a) case reports, case series and literature review type studies; b) non-original studies, including editorials, reviews and letters to the editor.

The articles included in the sample were read in their entirety, and the relevant data for the research was extracted and included in a worksheet containing the authors, year of publication, description of the sample and main conclusions of the study.

\section{Results}

Initially, the search strategies for examining the titles and abstracts of the articles resulted in 83 references. After analysis according to the eligibility criteria, 61 articles were deleted and 22 articles were retrieved and included in the final sample (Figure 1 and Table 1).

\section{Discussion}

Only 14 of the 22 articles analyzed assessed the epidemiological profile of the professionals at risk of skin cancer, noting a similarity of the data collected from the articles. The references analyzed noted that occupational skin cancer arises in individuals at more advanced ages, that is, from the sixth decade of life onward. . $^{69}$

The only discrepancy noted among the articles was that Lee et al..$^{10}$ conducted a case control study and noted that the average age of individuals with cutaneous malignant melanoma was 48.9 years, which did not differ much from the age of the control group. Even though this is an earlier age than that observed in other articles, this does not contradict the literature, as according to Korand et al. ${ }^{11}$ cutaneous melanoma has a higher incidence in the age range of 40 to 60 years of age.

Another variable of the epidemiological profile analyzed was that light-skinned individuals, that is, types I and II in the Fitzpatrick scale (light skin that burns easily, but never tans and light skin that burns easily and tans minimally, respectively) are more likely to develop skin cancer, as well as individuals of European descent. 7,8,10,12-16

Most of the articles that analyzed the epidemiological profile noted that workers who had risk factors for occupational skin cancer have, in general, a low level of education, which is consistent with the literature, given that this favors these professionals not being aware of the risk factors for skin cancer and preventive measures. Also, the lower the educational level, the greater the tendency to work for larger periods, whether hours or days of work, than those with a higher level of education. ${ }^{15,17-19}$

For Hammond et al. ${ }^{14}$ their study observed professions at risk of skin cancer, who were builders, gardeners and road workers. These had a larger percentage of workers with secondary education, noting that they had a greater knowledge of preventive measures against skin cancer, since those who had an average risk of developing this neoplasm protected themselves less than those with a high risk. However, the sample of these workers was small, and may not have provided sufficient evaluation because the workers composing the sample might not have known the preventative measures for this neoplasm.

The risk factors of skin cancer for professionals in the work environment were analyzed in 16 articles selected in this study. Ten of these 16 articles noted that sun exposure is the main factor of occupational risk. Ultraviolet radiation reaches the Earth's surface every day; therefore, professionals in the outdoor environment have a high risk of sun exposure and consequent risk of skin cancer., ${ }^{46-8,8,12,18-22}$

In view of this, it has been observed that chronic and excessive exposure in the first 10 to 20 years of life, especially at times when the sun's rays are more intense, this is, from 10 am to $4 \mathrm{pm}$, increases the risk of skin cancer, as at a young age there is a higher chance of cumulative sun exposure in the workplace. ${ }^{18,19}$ According to Simões et al. ${ }^{19}$ builders are professionals at risk, as they have a 44 hour work week, with excessive exposure to UV rays.

Popim et al. ${ }^{18}$ analyzed postal workers in the city of Botucatu, SP, Brazil and assessed that these professionals are exposed to variables that can promote the emergence of skin cancer, namely: Skin color, as white skin of- 
fers less protection against the sun's rays; being young; time and duration of sun exposure and residing in a tropical environment, that is, in a hot climate.

Another study that presented these same risk factors was that of Ferreira, Nascimento and Rotta, ${ }^{8}$ adding a positive family history of skin cancer, as well as noting that the number of hours of non-occupational sun exposure doubles the chance of developing a non-melanoma skin cancer.

Other studies have evaluated other professions which have sun exposure as risk factors. Oliveira, Glauss and $\mathrm{Palma}^{4}$ evaluated that physical education instructors for water based activities are vulnerable due to unsuitable conditions in the workplace; Hiemstra, Glanz and Nehl ${ }^{21}$ observed that prior sunburn is an important predictor for future burns in lifeguards, and is also a risk factor for skin cancer. Likewise, Duffy et al., ${ }^{7}$ found that operating engineers have excessive exposure to UV light and a low rate of use of sunscreen.

Two studies evaluated flight crews, with one finding that the incidence of melanoma in the skin among the flight crew rose with the increase in the number of hours flown, although it may have occurred due to sun exposure during leisure time and not at work, as the areas of

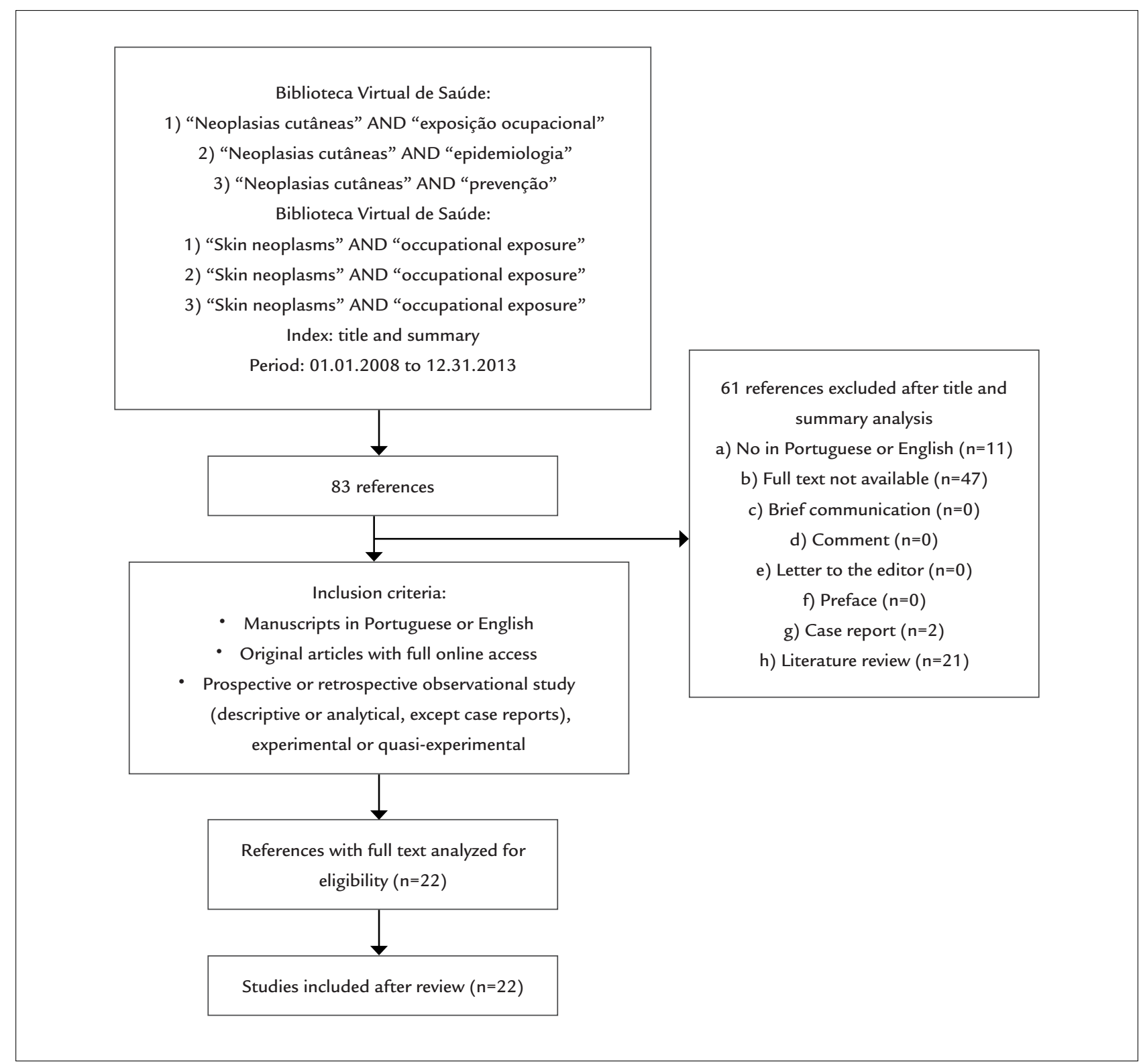

FIGURE 1 Flowchart summarizing the process of selection of studies for this review. 
TABLE 1 Shows an overview of all the studies included in the final sample and all the data collected and used for the sample analysis process.

\begin{tabular}{|c|c|c|c|}
\hline Author (year) & Journal & Sample & Main findings \\
\hline $\begin{array}{l}\text { Borsato; Nunes } \\
(2009)\end{array}$ & $\begin{array}{l}\text { Ciência, Cuidado e } \\
\text { Saúde }\end{array}$ & $\begin{array}{l}181 \text { cases of skin cancer ( } 1 \text { was melanoma } \\
\text { and } 180 \text { were non-melanoma cancer) }\end{array}$ & $\begin{array}{l}\text { The main professions related to the risk of developing } \\
\text { non-melanoma skin cancer are rural workers, general } \\
\text { services, trade and construction }\end{array}$ \\
\hline $\begin{array}{l}\text { Caroe et al. } \\
(2013)\end{array}$ & $\begin{array}{l}\text { Danish Medical } \\
\text { Journal }\end{array}$ & $\begin{array}{l}36 \text { patients with a diagnosis of occupational } \\
\text { skin cancer recognized by the National Board } \\
\text { of Industrial Injuries in Denmark }\end{array}$ & $\begin{array}{l}\text { The professions affected most by non-melanoma skin } \\
\text { cancer were gardening and construction work }\end{array}$ \\
\hline $\begin{array}{l}\text { Chang et al. } \\
\text { (2009) }\end{array}$ & $\begin{array}{l}\text { International Journal } \\
\text { of Epidemiology }\end{array}$ & $\begin{array}{l}15 \text { case-control studies }(5,700 \text { cases of } \\
\text { melanoma and } 7,216 \text { controls })\end{array}$ & $\begin{array}{l}\text { Occupational exposure to sunlight is a risk factor for } \\
\text { cutaneous melanoma in exposed areas, mainly in low- } \\
\text { latitude areas }\end{array}$ \\
\hline $\begin{array}{l}\text { Dennis et al. } \\
(2010)\end{array}$ & $\begin{array}{l}\text { Environmental Health } \\
\text { Perspective }\end{array}$ & $\begin{array}{l}150 \text { pesticide applicators with incidence of } \\
\text { cutaneous melanoma and } 24,554 \text { pesticides } \\
\text { applicators without cutaneous melanoma }\end{array}$ & $\begin{array}{l}\text { Contact with certain pesticides evaluated in the study } \\
\text { may increase the risk of developing cutaneous } \\
\text { melanoma }\end{array}$ \\
\hline $\begin{array}{l}\text { Duffy et al. } \\
(2012)\end{array}$ & $\begin{array}{l}\text { American Journal of } \\
\text { Industrial Medicine }\end{array}$ & 498 operating engineers & $\begin{array}{l}\text { Operating engineers have a high risk of developing } \\
\text { skin cancer, but a low adherence to the preventive } \\
\text { measures }\end{array}$ \\
\hline $\begin{array}{l}\text { Ferreira; } \\
\text { Nascimento; } \\
\text { Rotta (2011) }\end{array}$ & $\begin{array}{l}\text { Revista da Associação } \\
\text { Médica Brasileira }\end{array}$ & $\begin{array}{l}132 \text { cases of non-melanoma skin cancer and } \\
132 \text { controls (individuals without skin cancer/ } \\
\text { with other skin conditions) treated and/or } \\
\text { monitored at the Dermatology Service of } \\
\text { Taubaté }\end{array}$ & $\begin{array}{l}\text { The risk factors associated with non-melanoma skin } \\
\text { cancer are: light skin, number of hours of occupational } \\
\text { and non-occupational exposure and a family history } \\
\text { of skin cancer }\end{array}$ \\
\hline $\begin{array}{l}\text { Hall et al. } \\
(2009)\end{array}$ & Arch Dermatology & 1,640 lifeguards and swimming instructors & $\begin{array}{l}\text { The lifeguards use some sun protection measures in } \\
\text { the workplace, but not in a satisfactory manner }\end{array}$ \\
\hline $\begin{array}{l}\text { Hammond et al. } \\
\text { (2009) }\end{array}$ & $\begin{array}{l}\text { Health Promotion } \\
\text { Journal of Australia }\end{array}$ & $\begin{array}{l}74 \text { workers from three outdoor occupational } \\
\text { groups (horticulture, road and civil construction } \\
\text { workers) }\end{array}$ & $\begin{array}{l}\text { Prevention measures against occupational skin cancer } \\
\text { become satisfactory when associated with programs } \\
\text { to support sun protection practices in the workplace }\end{array}$ \\
\hline $\begin{array}{l}\text { Hiemstra; Glanz; } \\
\text { Nehl (2012) }\end{array}$ & $\begin{array}{l}\text { Journal of the } \\
\text { American Academy of } \\
\text { Dermatology }\end{array}$ & 3,014 lifeguards & $\begin{array}{l}\text { The lifeguards are exposed to excessive solar radiation } \\
\text { in the work environment, and it was observed that } \\
\text { professionals with a previous history of burns are likely } \\
\text { to have future burns, favoring the emergence of skin } \\
\text { cancer }\end{array}$ \\
\hline Lee et al. (2009) & Melanoma Research & $\begin{array}{l}595 \text { cases of cutaneous melanoma and } 595 \\
\text { controls }\end{array}$ & $\begin{array}{l}\text { The study showed that individuals with high levels of } \\
\text { occupational physical activity have a greater risk of } \\
\text { developing cutaneous melanoma }\end{array}$ \\
\hline $\begin{array}{l}\text { Malak et al. } \\
(2011)\end{array}$ & $\begin{array}{l}\text { Asian Pacific Journal } \\
\text { of Cancer Prevention }\end{array}$ & $\begin{array}{l}194 \text { individuals from a village in the Marmara } \\
\text { Region (Western Turkey) }\end{array}$ & $\begin{array}{l}\text { Before the training conducted in the study, the farmers } \\
\text { had insufficient knowledge about skin cancer and the } \\
\text { harmful effects of the sun }\end{array}$ \\
\hline $\begin{array}{l}\text { Mccool et al. } \\
(2009)\end{array}$ & $\begin{array}{l}\text { Journal of } \\
\text { Occupational Health }\end{array}$ & $\begin{array}{l}\text { 1,131 outdoor workers from nine occupational } \\
\text { groups }\end{array}$ & $\begin{array}{l}\text { Males and young people have a higher risk of } \\
\text { developing skin cancer }\end{array}$ \\
\hline $\begin{array}{l}\text { Nicholas; } \\
\text { Swearingen; } \\
\text { Kilmer (2009) }\end{array}$ & $\begin{array}{l}\text { Occupational } \\
\text { Medicine }\end{array}$ & $\begin{array}{l}2,428 \text { active pilots from four airlines based } \\
\text { in the USA }\end{array}$ & $\begin{array}{l}\text { The risk factors for non-melanoma skin cancer in air } \\
\text { pilots are: skin types; sunburn in childhood and family } \\
\text { history of non-melanoma skin cancer, and may be } \\
\text { associated with flight time at high latitude }\end{array}$ \\
\hline $\begin{array}{l}\text { Oliveira; Glauss; } \\
\text { Palma (2011) }\end{array}$ & $\begin{array}{l}\text { Anais Brasileiros de } \\
\text { Dermatologia }\end{array}$ & $\begin{array}{l}123 \text { teachers with at least one year of } \\
\text { professional practice in water based activities } \\
\text { ( } 70 \text { male and } 53 \text { female professionals) }\end{array}$ & $\begin{array}{l}\text { Water based physical education professionals are } \\
\text { vulnerable to skin cancer, as most people don't protect } \\
\text { themselves appropriately in the workplace }\end{array}$ \\
\hline
\end{tabular}


TABLE 1 (Cont.) Shows an overview of all the studies included in the final sample and all the data collected and used for the sample analysis process.

\begin{tabular}{|c|c|c|c|}
\hline Author (year) & Journal & Sample & Main findings \\
\hline $\begin{array}{l}\text { Popim et al. } \\
(2008)\end{array}$ & $\begin{array}{l}\text { Ciência \& Saúde } \\
\text { Coletiva }\end{array}$ & $\begin{array}{l}33 \text { postal workers for the Brazilian Postal } \\
\text { Service in Botucatu }\end{array}$ & Postal workers are a risk group for skin cancer \\
\hline $\begin{array}{l}\text { Reeder; Gray; } \\
\text { Mccool (2013) }\end{array}$ & $\begin{array}{l}\text { Journal of } \\
\text { Occupational Health }\end{array}$ & 1,061 workers & $\begin{array}{l}\text { There is a difference in the form of primary prevention } \\
\text { for skin cancer among the various occupations } \\
\text { examined, but this protection is not performed } \\
\text { satisfactorily }\end{array}$ \\
\hline $\begin{array}{l}\text { Schernhammer } \\
\text { et al. (2011) }\end{array}$ & $\begin{array}{l}\text { Journal of the } \\
\text { National Cancer } \\
\text { Institute }\end{array}$ & 68,336 white, non-Hispanic nurses & $\begin{array}{l}\text { The professionals who work the night shift have less } \\
\text { risk of developing skin cancer }\end{array}$ \\
\hline $\begin{array}{l}\text { Silva et al. } \\
(2013)\end{array}$ & $\begin{array}{l}\text { International Journal } \\
\text { of Cancer }\end{array}$ & $\begin{array}{l}16,329 \text { crew members and 3,165 air traffic } \\
\text { control officers }\end{array}$ & $\begin{array}{l}\text { The crew members present high rates of melanoma } \\
\text { in relation to the general population }\end{array}$ \\
\hline $\begin{array}{l}\text { Simões et al. } \\
(2011)\end{array}$ & $\begin{array}{l}\text { Revista Gaúcha de } \\
\text { Enfermagem }\end{array}$ & $\begin{array}{l}50 \text { workers at a construction company in Rio } \\
\text { de Janeiro }\end{array}$ & $\begin{array}{l}\text { The knowledge of workers about the causes that may } \\
\text { lead to emergence of skin cancer is relevant, as well } \\
\text { as the prevention methods }\end{array}$ \\
\hline $\begin{array}{l}\text { Stock et al. } \\
(2009)\end{array}$ & $\begin{array}{l}\text { Annals of Behavioral } \\
\text { Medicine }\end{array}$ & 148 male, outdoor workers & $\begin{array}{l}\text { UV photography interventions may encourage the } \\
\text { reduction of UV exposure in outdoor workers }\end{array}$ \\
\hline $\begin{array}{l}\text { Surdu et al. } \\
(2013 a)\end{array}$ & PLOS ONE & $\begin{array}{l}618 \text { cases of non-melanoma skin cancer and } \\
527 \text { controls among white residents from three } \\
\text { European countries (eight cities located in } \\
\text { Hungary, Romania and Slovakia) }\end{array}$ & $\begin{array}{l}\text { The study showed an inverse association between } \\
\text { exposure to natural and artificial UV radiation and } \\
\text { the risk of non-melanoma skin cancer }\end{array}$ \\
\hline $\begin{array}{l}\text { Surdu et al. } \\
\text { (2013b) }\end{array}$ & $\begin{array}{l}\text { International Journal of } \\
\text { Cancer }\end{array}$ & $\begin{array}{l}618 \text { incident cases of non-melanoma skin } \\
\text { cancer and } 527 \text { controls }\end{array}$ & $\begin{array}{l}\text { There is risk of developing non-melanoma skin cancer } \\
\text { in women exposed to arsenic in the workplace }\end{array}$ \\
\hline
\end{tabular}

the body most affected were covered by clothing, such as the lower limbs and trunk. ${ }^{16}$

Another article found that being a pilot for more than 20 years is a risk factor for non-melanoma skin cancer, especially in the case of professionals with more flight time at high latitude, as this increase exposure to ionizing radiation. ${ }^{7}$ We may conclude that the first article was inconsistent with the others assessing exposure to solar radiation in the workplace, but this may have been due to some limitations, such as lack of determination of cosmic radiation to which the flight crew was exposed and the possibility that some results may have arisen by chance because of the large number of comparisons.

Another article that presented a contradiction was the study of Surdu et al., ${ }^{23}$ which showed an inverse relationship between non-melanoma skin cancer, primarily basal cell carcinoma (BCC), and sun exposure in the workplace. However, this article presented limitations that may have favored this contradiction, as the evaluation of sun exposure may have been misclassified, or participants may have had low levels of sun exposure, as well as having been protected against UV exposure, leading to these professionals not developing skin cancer.
It was observed that the professions related to the risk of developing skin cancer in the workplace were outdoor workers. ${ }^{6}, 12$ According to Caroe et al., ${ }^{6}$ gardening and construction were the occupations with the highest amount of non-melanoma skin cancer due to exposure to UV radiation. Meanwhile, Borsato and Nunes ${ }^{12}$ present rural works followed by general services workers, trade and construction as professionals at risk of non-melanoma skin cancer.

Therefore, articles that have rated the professions of outdoor workers as being at greater risk of skin cancer have presented construction and farm workers as the most cited professions, and we can conclude that these are the most at risk. ${ }^{6,9,12,14,15,19,24}$

In addition to solar radiation, workers can have other risk factors of an occupational order, including arsenic, tar, mineral oils and lubricants, among others, but which also require prolonged and chronic exposure to such substances. ${ }^{12}$

According to Surdu et al.,23 women exposed to arsenic in the workplace have a high incidence of BCC in regions exposed to solar radiation, such as the face, scalp and neck. They also noted that there is no increased risk 
in the absence of occupational exposure to sunlight. However, this conclusion is not significant because it was based on only four exposed controls.

Nevertheless, it is believed that chronic arsenic exposure increases the mutagenicity of other carcinogens, such as UV radiation. ${ }^{23}$ Dennis et al..$^{25}$ found a consistent association of melanoma and pesticide applicators, due to contact with pesticides containing arsenic, as well as pesticides containing maneb/mancozeb and parathion.

The absence of UV exposure can be a protective factor for skin cancer, as Schernhammer et al. ${ }^{26}$ noted that nurses with more than 10 years of nighttime work have less chance of developing skin cancer than nurses who never worked on the night shift. For McCool et al., ${ }^{24}$ sun exposure is a risk factor present in the environment of outdoor work, but modifying the work shift to reduce this risk is often not feasible. Therefore, other alternative measures should be taken, consisting of the use of sunscreen to reduce excessive exposure to UV rays.

According to Lee et al., ${ }^{10}$ the case control study participants who had high levels of occupational activities have an increased risk of cutaneous malignant melanoma; however, this article had no statistical significance and no dose-response relationship was observed. The article by Chang et al. ${ }^{20}$ noted that the risk of melanoma to the head and neck is increased in workers exposed to the sun, especially at low latitudes due to high temperatures.

The prevention of occupational skin cancer occurs when there is a contact protection of causative agents of cellular damage in the workplace with the skin of the professionals. Prevention measures were examined in eight articles, which noted a predominance of the use of the following sun protection equipment: sunscreen, hats, caps, long pants, long-sleeve shirts, sunglasses and sunshades. ${ }^{3,4,13-16,18,19,24}$

The protection measures were used significantly more among women, especially sunscreen. ${ }^{4,13,16,24}$ According to $\mathrm{McCool}$ et al., ${ }^{24}$ males and younger people have a lower index of adherence to the use of protective equipment because they underestimate the risk and overestimate the ability to cope with that risk.

There was a contradiction among the articles in the assessment of the protection method most widely used in the workplace. In the study conducted by $\mathrm{McCool}$ et al., ${ }^{24}$ the authors found that viticulture, landscaping and postal workers used more sunscreen than the other professional groups evaluated in the study. For Hall et al., ${ }^{13}$ the most common protection method among the lifeguards was the use of sunglasses.
Reeder, Gray and McCool, ${ }^{15}$ concluded that the equipment used most by professionals was "any kind of hat", but less than a third of these were wide-brimmed to protect the areas that usually develop skin cancer, namely, the face, ears and neck, and the profession that showed the highest protection index among those studied was viticulture. According to this study, only $5 \%$ of the sample reported not using sun protection measures, but the method of protection was being performed in an unsatisfactory manner.

In view of this, the encouragement of programs for prevention of skin cancer associated with intervention measures in health and safety at work are recommended, because in order for this protection to be effective this association must be consolidated and be relevant to the professional groups.

According to Hall et al., ${ }^{13}$ lifeguards teaching lessons in swimming pools presented higher protection scores, although while reporting that they perform these protective measures, more than half of these professionals reported having had sunburn at least once, further indicating the need to improve solar safety measures. Therefore, it was concluded that even after providing the equipment, if there is no incentive the professionals do not value its use. ${ }^{18}$

For Stock et al., ${ }^{3}$ the use of UV photography and information about skin cancer intervention to reduce exposure to sunlight in male outdoor workers was effective. Likewise, the media is an important communication tool for spreading information about prevention and promotion of health. This article also noted that the workplace was cited as a means of disseminating preventive measures, therefore there is a need to improve safety conditions in the workplace, that is, to provide personal protective equipment, as well as investing in programs encouraging the use of such equipments and teaching the correct way to use them. ${ }^{19}$

\section{Conclusion}

We conclude that sun exposure is the main occupational risk factor for skin cancer, with a higher incidence in rural and construction workers. Few articles assessing other causative agents of occupational skin cancer beyond solar radiation were retrieved, as well as professions that do present sunlight as the main risk factor. As such, this review shows the need for further studies to investigate other professions and risk factors that may be associated with this occupational cancer.

Our study revealed that professionals do not protect themselves properly in the work environment, and that 
greater investments by companies in worker health are required through the provision of protective equipment. In addition, prevention and health promotion programs should be encouraged, as well as providing easier access to information on the correct forms of protection.

\section{Resumo}

Câncer de pele ocupacional: revisão sistemática

Objetivo: analisar o perfil epidemiológico, os fatores de risco no ambiente de trabalho e os métodos de prevenção dos profissionais de risco para câncer de pele.

Método: foi realizada uma revisão sistemática de artigos sobre o câncer de pele ocupacional, publicados entre 1 de janeiro de 2008 e 31 de dezembro de 2013, nas bases de dados Lilacs, Scielo, Medline e Biblioteca Cochrane. A pesquisa baseou-se na intersecção dos seguintes termos: "neoplasias cutâneas" (DeCS), "exposição ocupacional" (DeCS), "epidemiologia" (DeCS) e a palavra-chave "prevenção" e seus equivalentes em inglês.

Resultados: após a análise dos títulos e resumos dos artigos, a estratégia de busca resultou em 83 referências, das quais 22 artigos preencheram os critérios de elegibilidade.

Discussão: a exposição solar é o principal fator de risco ocupacional para câncer de pele e os trabalhadores ao ar livre são os mais vulneráveis a desenvolvê-lo. Aqueles com baixo nível de escolaridade e ascendência europeia apresentam maior risco de desenvolver a neoplasia.

Conclusão: os trabalhadores ao ar livre são mais vulneráveis a desenvolver câncer de pele ocupacional. Os profissionais com baixo nível de escolaridade e ascendência europeia apresentam maior risco de desenvolver a neoplasia. São necessários mais investimentos das empresas na saúde dos trabalhadores por meio de fornecimento de equipamentos de proteção, a fim de prevenir o câncer de pele ocupacional.

Palavras-chave: neoplasias cutâneas, exposição ocupacional, prevenção de doenças, epidemiologia.

\section{REFERENCES}

1. Ribeiro FSN, Wunsch Filho V. Avaliação retrospectiva da exposição ocupacional a cancerígenos: abordagem epidemiológica e aplicação em vigilância em saúde. Cad Saúde Pública. 2004; 20(4):881-0.

2. BRASIL, Ministério da Saúde. Instituto Nacional do Câncer (INCA). Diretrizes para a vigilância do câncer relacionado ao trabalho. Rio de Janeiro, 2012.

3. Stock ML, Gerrard M, Gibbons FX, Dykstra JL, Weng CY, Mahler HI, et al. Sun protection intervention for highway workers: long-term efficacy of UV photography and skin cancer information on men's protective cognitions and behavior. Ann Behav Med. 2009; 38(3):225-36.

4. Oliveira LMC, Glauss N, Palma A. Hábitos relacionados à exposição sola dos professores de educação física que trabalham com atividades aquáticas An Bras Dermatol. 2011; 86(3):445-0.

5. Diepgen TL, Fartasch M, Drexler H, Schmitt J. Occupational skin cancer induced by ultraviolet radiation and its prevention. Br J Dermatol. 2012; 167(Suppl 2):76-84.

6. Carøe TK, Ebbehøj NE, Wulf HC, Agner T. Occupational skin cancer may be underreported. Dan Med J. 2013; 60(5):A4624.

7. Duffy SA, Choi SH, Hollern R, Ronis DL. Factors associated with risky sun exposure behaviors among operating engineers. Am J Ind Med. 2012; 55(9):786-2.

8. Ferreira FR, Nascimento LFC, Rotta O. Fatores de risco para câncer da pele não melanoma em Taubaté, SP: um estudo caso-controle. Rev Assoc Med Bras. 2011; 57(4):431-7.

9. Surdu S, Fitzgerald EF, Bloom MS, Boscoe FP, Carpenter DO, Haase RF, et al. Occupational exposure to ultraviolet radiation and risk of nonmelanoma skin cancer in a multinational European study. PLoS One 2013; 8(4):e62359.

10. Lee TK, MacArthur AC, Gallagher RP, Elwood MJ. Occupational physical activity and risk of malignant melanoma: the Western Canada Melanoma Study. Melanoma Res. 2009; 19(4):260-6.

11. Konrad P, Fabris RM, Melao S, Blanco LFO. Perfil epidemiológico e histopatológico dos casos de melanoma cutâneo primário diagnosticados em Criciúma no período entre 2005 e 2007. An Bras Dermatol. 2011; 86(3):457-61.

12. Borsato FG, Nunes EFPA. Neoplasia de pele não melanoma: um agravo relacionado ao trabalho. Ciênc Cuid Saúde. 2009; 8(4):600-6.

13. Hall DM, McCarty F, Elliott T, Glanz K. Lifeguards' sun protection habits and sunburns: association with sun-safe environments and skin cancer prevention program participation. Arch Dermatol. 2009; 145(2):139-4.

14. Hammond V, Reeder AI, Gray AR, Bell ML. Are workers or their workplaces the key to occupational sun protection? Health Promot J Austr. 2008; 19(2):97-1.

15. Reeder AI, Gray A, McCool JP. Occupational sun protection: workplace culture, equipment provision and outdoor workers' characteristics. J Occup Health. 2013; 55(2):84-97.

16. Silva IS, Stavola B, Pizzi C, Evans AD, Evans SA. Cancer incidence in professional flight crew and air traffic control officers: disentangling the effect of occupational versus lifestyle exposures. Int J Cancer. 2013; 132(2):374-84.

17. Malak AT, Yildirim P, Yildiz Z, Bektas M. Effects of training about skin cancer on farmers' knowledge level and attitudes. Asian Pac J Cancer Prev. 2011; 12(1):117-20.

18. Popim RC, Corrente, JE, Marino, JAG, Souza CA. Câncer de pele: uso de medidas preventivas e perfil demográfico de um grupo de risco na cidade de Botucatu. Ciênc Saúde Coletiva. 2008; 13(4):1331-6.

19. Simões TC, Souza NVDO, Shoji S, Peregrino AAF, Silva D. Medidas de prevenção contra câncer de pele em trabalhadores da construção civil: contribuição da enfermagem. Rev Gaúcha Enferm. 2011; 32(1):100-6.

20. Chang YM, Barrett JH, Bishop DT, Armstrong BK, Bataille V, Bergman W, et al. Sun exposure and melanoma risk at different latitudes: a pooled analysis of 5700 cases and 7216 controls. Int J Epidemiol. 2009; 38(3):814-30.

21. Hiemstra M, Glanz K, Nehl E. Changes in sunburn and tanning attitudes among lifeguards over a summer season. J Am Acad Dermatol. 2012; 66(3):430-7.

22. Nicholas JS, Swearingen CJ, Kilmer JB. Predictors of skin cancer in commercial airline pilots. Occup Med (Lond). 2009; 59(6):434-6.

23. Surdu S, Fitzgerald EF, Bloom MS, Boscoe FP, Carpenter DO, Haase RF, et al. Occupational exposure to arsenic and risk of nonmelanoma skin cancer in a multinational European study. Int J Cancer. 2013; 133(9):2182-91.

24. McCool JP, Reeder AI, Robinson EM, Petrie KJ, Gorman DF. Outdoor workers perceptions of the risk of excessive sun-exposure. J Occup Health. 2009; 51(5):404-11.

25. Dennis LK, Lynch CF, Sandler DP, Alavanja MC. Pesticide use and cutaneous melanoma in pesticide applicators in the agricultural health study. Environ Health Perspect. 2010; 118(6):812-7.

26. Schernhammer ES, Razavi P, Li TY, Qureshi AA, Han J. Rotating night shifts and risk of skin cancer in the nurses' health study. J Nati Cancer Inst. 2011; 103(7):602-6. 